\title{
THE REALIZATION OF IMPOLITENESS STRATEGIES USED BY STUDENTS IN ENGLISH ONLINE LEARNING THROUGH ZOOM DURING PANDEMIC COVID-19
}

\author{
Suchroni Panjaitan \\ Sumarsih \\ Siti Aisah Ginting \\ English Applied Linguistics Study Program \\ Postgraduate Program-Universitas Negeri Medan
}

Diterima September; Disetujui Oktober; Dipublikasikan Desember

\begin{abstract}
Corona Virus Disease 2019 (COVID-19) was detected in China in December 2019, spread throughout the world within a few months and was declared a pandemic by the World Health Organization (WHO) on 11th March 2020. It also has hit Indonesia since March 2020. It affects $90.2 \%$ of students worldwide, in which 1.57 billion students are absent from school and 191 countries including Indonesia. Unfortunately, the observation found that the students often say impolite language, such as mock their friends, change their friends' name, and have high intonation when they were uttering their opinion during online teaching and learning process through Zoom. It is very serious problem because impoliteness happened during the main activity. The objective of the study was to find out the realizations of impoliteness strategies used by students in English online learning through Zoom during pandemic Covid-19. The study was descriptive qualitative. The subject of the study was VII grade of SMP Ar-Rahman Percut. The data of the study was impoliteness clauses which are recorded from the students' interaction. The finding of the study, there were eight realizations of impoliteness strategies found in this study, they are be disinterested, unconcerned, unsympathetic; use inappropriate identity marker; use obscure or secretive language; seek disagreement; use taboo words; call the other name; frighten; and condescend, scorn or ridicule. Then, there were three additional realizations, they are employing insincere; direct speech, clear, unambiguous; and invade the other's space.
\end{abstract}

Keywords: Impoliteness, Students in English Online Learning, Zoom, Covid-19

How to Cite: Panjaitan, Suchroni. (2021). The Realization of Impoliteness Strategies Used by Students in English Online Learning through Zoom during Pandemic Covid-19. Jurnal Linguistik Terapan Pascasarjana Unimed. 18 (3): 253-264 . 


\section{INTRODUCTION}

Corona Virus Disease 2019 (COVID-19) was detected in China in December 2019, spread throughout the world within a few months and was declared a pandemic by the World Health Organization (WHO) on 11th March 2020. It also has hit Indonesia since March 2020. It affects $90.2 \%$ of students worldwide, in which 1.57 billion students are absent from school and 191 countries including Indonesia. This condition is what makes the government to change the overall conditions of learning and teaching in Indonesia by forming a new learning and teaching system namely online schools or home studies were conducted from March 2020. According to Chambers, Varoglu and Buddeberg (2016) online learning is one part of Online and Distance Learning (ODL), an umbrella term that refer to a variety of learning practices: e-learning, distance learning, learning through correspondence, flexible learning and Massive Online Course Movement/MOCM. There are four characters of ODL itself, they are: the separation of teachers and students both in time and space, the use of technology, learning experiences that are more individual and include two-way communication and wider networks.

In online learning, teachers can learn together at the same time through various platforms such as Zoom Application, Google Meet, Google Classroom, WhatsApp (WA), Telegram and other platform. Online learning is carried out by various levels of education, starting from elementary, junior high school, senior high school and college levels. And it is in line with Surat Edaran Nomor 4 Tahun 2020 tentang Pelaksanaan Kebijakan Pendidikan dalam Masa Darurat Penyebaran COVID-19 which says learning from home through online/distance learning is carried out to provide a learning experience for students without being burdened with the demands of completing all curriculum achievements for grade promotion and graduation, learning from home can be focused on life skills education, including the Covid-19 pandemic, activities and assignments from home may vary according to the interests and conditions of each student, including considering access/learning facilities at home, and learning activity products from home are given qualitative and useful feedback from the teacher, without being required to give quantitative scores/values. To support this situation, the Ministry of Education and Culture of Indonesia has also set various policies, such as cooperating with TVRI to broadcast learning from home programs and allowing using BOS (Bantuan Operasional Sekolah) in online learning and buy internet credit. So, the teacher can ensure students take part in learning at the same time, even in different places. 
In online learning system during pandemic Covid-19 resulted in extraordinary changes to all levels of education, one of which is about character education. Schools are an important component to implement positive values in the development of character education for students. Schools also as a second place to carry out socialization and structured education when compared to activities at home that are relatively incidental, so schools have an important role in realizing students to become students who have good personalities in accordance with the values of the nation's character. Unfortunately, from observation that found the students especially in seventh grade often say impolite language, such as mock their friends, change their friends' name, and have high intonation when they were uttering their opinion during online teaching and learning process through Zoom. It is very serious problem because impoliteness happened during the main activity. Dagarin (2004) believes that interaction is mainly achieved by two means of resources: verbal and non-verbal, so that the participants can interact each other to express ideas and feelings through both verbally and nonverbally in both polite and impolite way.

Besides the fact above, it also conducted an interview to get information from the English teacher and other subjects in seventh grade about impoliteness that uttered by students. The teacher said that impoliteness does not only occur in English online learning, but also in other subjects or at home. Impolite expressions cannot be avoided by the students in online learning because of some factors, they are the students in seventh grade do not have good language skill because the teachers and students met only within a certain time so the teachers do not have specific time to teach the students' characters; the student's environment can't be good role model in shaping students' as we know that the students will spend time at home or in the neighborhood so that the attitudes of parents, family and friends that do not reflect the norms of politeness will be easily imitated by children; the parents conveyed the right to the teachers to educate their children because they are working outside from morning to evening; and the use of mobile phone for game online and social media.

Impoliteness is an utterance or a behavior when it comes to gathering in other community. According to Walaszewska and Piskorska (2012), impoliteness is an utterance that produce disharmony between individual and other people in social interactions. It means impoliteness is an utterance that causes a disharmony relationship between individuals. In doing this study, Culpeper (1996) divides the realization of impoliteness into eleven categories, they are: ignore, snub the other; disassociate from the other; be disinterested, unconcerned, unsympathetic; use inappropriate identity markers; use obscure or secretive language; seek disagreement/ avoid agreement; use taboo words; call the other name; threaten/ frighten; 
condescend, scorn or ridicule; explicitly associate the other with a negative aspect. This impoliteness phenomenon can be found in online learning. This impoliteness phenomenon can be found in online learning. The situation happens among students at SMP Ar-Rahman Percut.

\section{AF : Alhamdulillah... akhirnya si aseng geleng datang juga. (Alhamdulillah... finally aseng geleng comes) \\ RA : Miss... dia suka kali bilang saya gitu. \\ (Miss... he often calls me like that)}

From the data above, "aseng geleng" is realized as using call the other name is one of the output strategies of positive impoliteness proposed by Culpeper (1996). In doing this research, there were several previous researches concerned on impoliteness, one of them comes from Anggriani (2016) investigated a research about impoliteness used by haters in celebrities' Instagram. It was to describe the realization of language impoliteness which is used by haters in celebrities' Instagram. The result showed that the realizations of language impoliteness were done through be disinterested, unconcerned, unsympathetic, use inappropriate identity markers, use obscure or secretive language, seek disagreement, use taboo words, call the other names, frighten, condescend, scorn or ridicule, personalize/ pronoun, and other realizations were found, namely insult and similes.

Considering the phenomena, the researcher is curious to do research at investigating the clauses contain with impoliteness that involves in English online learning. Then, this study focused on the impoliteness strategies in English online learning used by students in order to elaborate the realization of impoliteness strategies which are used by students in online learning through Zoom.

\section{METHODOLOGY}

Qualitative research is an umbrella term to refer to several research strategies that share certain characteristics. The data collected have been term soft, which is rich in description of people, places, and conversations, and not easily handled by statistical procedures (Bogdan and Biklen, 2007). The data of the study were collected from clauses contain of impoliteness. The source of data was the students' in English online learning for seventh grade of SMP Ar-Rahman Percut. This data was taken only in seventh grade with consists of 4 classes. Those are 7A, 7B, 7C and 7D. The subjects taken as a sample were completely based on the desired characteristics, criteria and needs of the research. The instruments that are used in this research:

1. Recording students' interaction. Zoom application was used in recording the students 
English online learning. The data was recorded in ten meetings of English online learning.

2. Transcribing the data have produced by students.

3. Observing the students' utterances which are considered as clauses that contain to impoliteness.

4. Listing the impolite clauses that used by students in order to the types, realizations and the reasons.

5. Interviewing the students for using impolite language and the teacher and parents why the students used impolite language.

All the data were analyzed and described based on the realizations of language impoliteness used by students in English online learning through Zoom.

\section{FINDING AND DISCUSSION}

After analyzing the clauses, it was found 11 realizations of impoliteness strategies. It was found 8 realizations of impoliteness strategies used by students based on the theory from Culpeper (1996) and also found 3 additional realizations namely employing insincere, direct speech, clear, unambiguous, and invade the other's space.

Table 1. Realizations of impoliteness Strategies used by students

\begin{tabular}{llcc}
\hline No & \multicolumn{1}{c}{ Realizations of Impoliteness Strategies } & Total & $\begin{array}{c}\text { Percentages } \\
(\mathbf{\%})\end{array}$ \\
\hline 1. & Employing insincere & 14 & 20.59 \\
2. & Condescend, scorn or ridicule & 13 & 19.12 \\
3. & Direct speech, clear, unambiguous & 10 & 14.71 \\
4. & Use taboo words & 8 & 11.76 \\
5. & Call the other name & 6 & 8.82 \\
6. & Disinterested, unconcerned, unsympathetic & 5 & 7.35 \\
7. & Frighten & 4 & 5.88 \\
8. & Seek disagreement & 3 & 4.41 \\
9. & Use inappropriate identity marker & 3 & 4.41 \\
10. & Invade the other's space & 1 & 1.47 \\
11. & Obscure or secretive language & 1 & 1.47 \\
\hline & & $\mathbf{6 8}$ & $\mathbf{1 0 0}$ \\
\hline
\end{tabular}

The following point would provide the analysis of realizations of impoliteness strategies found in the following description below.

\section{Employing insincere}

After analyzing the data, it was found 14 clauses realize with employing insincere. It performs with the use of politeness strategies. Politeness which can be interpreted is an impolite way because of certain contextual clues and the intention of not causing offense but rather to show social intimacy. It can be seen from the representative data below. 


\author{
Data 7 \\ Aud \\ : $\quad$ My brother and I ... pop singer. Jadi saya jawabnya 'am' kok salah ya \\ miss? Kan pasangan I itu am \\ (The question is 'My brother and I ... pop singer'. So, my answer was \\ 'am', but it was not correct) \\ T : Benar kalau kamu bilang pasangannya "am”. Tapi yang minta bukan \\ itu. Ada yang tau jawabannya apa? \\ (That's correct if you said like that. But, it's not what I asked for. Is \\ there anyone who knows the answer?) \\ Fut : "Are" yakan miss jawabannya karena kan subjectnya disitu ada dua, \\ my brother sama I \\ (The answer is "are" because there were two subjects, my brother and \\ I) \\ D7/C054/Rah : Maye nih... katanya rangking satu \\ (How can... you said you got first rank)
}

From the conversation above, "maye nih... katanya rangking satu" showed that Rahmad was performing impolite utterances because of clearly insincere intention with the intention of not causing offense but rather to show social intimacy.

\title{
Condescend, scorn or ridicule
}

The criteria of this realization are stressing the relative power, humiliating, treating others not in a serious way, belittling others. From this realization, it was found 13 clauses realize with condescend, scorn or ridicule. It can be seen from the data below.

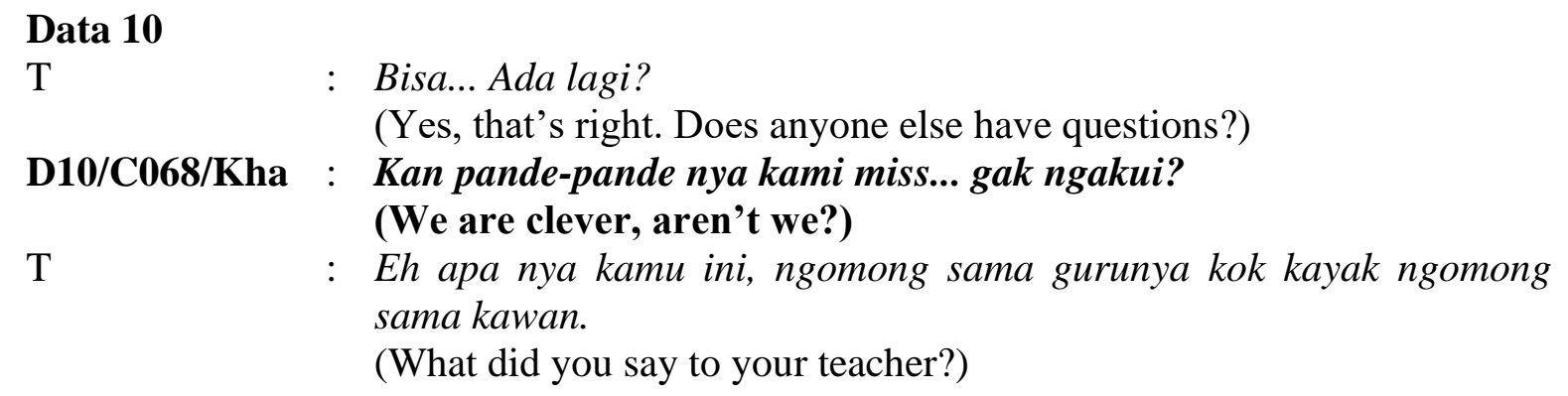

It showed that the student was condescending the teacher by saying "kan pande-pande nya kami miss... gak ngakui?". Condescend shows feeling of superiority or be patronizing. It is employed by someone when he or she feels smarter or stronger than others. In addition, there is another representative data from condescend, scorn or ridicule.

\section{Direct speech, clear, unambiguous}

An action threatening the face of the speech partner directly, clearly, unambiguously, and concisely when the face is irrelevant or minimized. After analyzing the data, it was found 
10 clauses realize with direct speech, clear and unambiguous. It can be seen from the following data below.

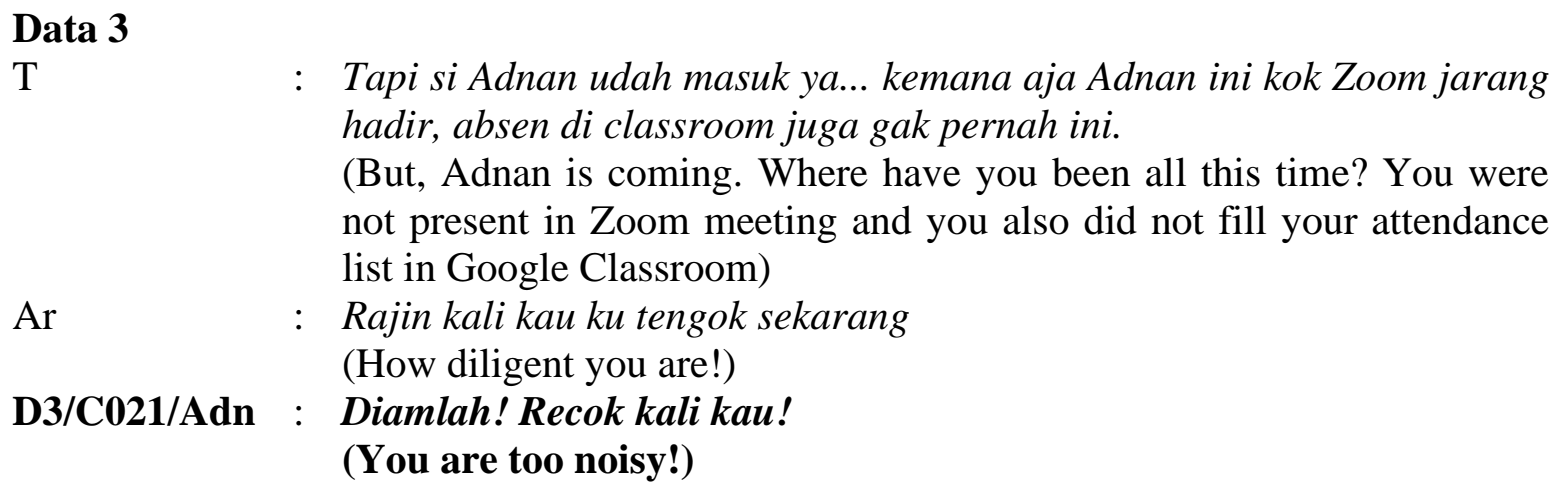

In this case, Arga insinuated Adnan by saying "rajin kali kau ya!" after that Adnan replied it by saying "diamlah! recok kali kau!" with using face attack and the first thing will do by other when someone is saying impolite utterances.

\section{Use taboo words}

By analyzing the data, it was found 8 clauses realize with taboo words. It is used by people to show their feeling such as angry, disappointment and dissatisfaction. It can be seen from the representative data below.

\section{Data 6 \\ Azr $\quad$ : Ya miss... dari belakang sama minum miss... (Yes, miss... I went to the kitchen to drink some water) \\ D6/C044/Ard : Bacot kali kau... (You talk too much)}

From data of taboo, the students can be replacing it with an appropriate word to say and hear. The data "bacot" can be replaced with "jangan mengarang cerita". It is expected that clause should not be mentioned and used by students especially in an educational environment.

\section{Call the other names}

It was found 6 clauses realize with call the other names after analyzing the data. It uses derogatory nominations. The data can be seen from the representative data below.

\section{Data 5}

\section{D5/C034/Fa : Heh Shireen Sungkar, gak shooting}

(Shireen Sungkar, don't you go for shooting today)

Shi : Lagi enggak shooting, Fajar...

(I am free, Fajar...) 
Based on the data above, the student called his classmates with the other name. In fact, Shireen is her real name which is the same as the name of a public figure in Indonesia, namely Shireen Sungkar. They have the same in their first name, Shireen. So that is why the male student calls her like that.

\section{Be disinterested, unconcerned, unsympathetic}

After analyzing the data, it was found 7 clauses realize with be disinterested, unconcerned, unsympathetic. It can be seen from the representative data below.

\section{Data 4 \\ Um : Belum dibeli mamak celananya miss... \\ D4/C024/Ail : Tak piker anyot hahahaha (My mother hasn't bought it yet) \\ (I think it floated off hahahaha)}

The clause that uttered by student "Tak piker anyot hahahaha" which showed unsympathetic. Unsympathetic can be defined as not feeling, showing, or expressing sympathy, and not showing, approval or favor toward an idea or action. It means that the impoliteness use for unsympathetic tack taken by one of the interactions. When the researcher did an interview to Umar, the researcher known that he is not a lucky person. He comes from lower middle-class family. He said that his mother decided to pay tuition first, then bought pants.

\section{Frighten}

Frighten is instill that action detrimental to the other will occur. It means that as with utterances which attack aspects of face concerned with approval, belonging and solidarity. It was found 4 clauses realize with be frighten by analyzing the data. It can be seen from the representative data below.

\section{Data 7}

$\mathrm{T}$

: Iya benar, seperti itu dia Audy... sudah mengerti kan Audy?

(Yes, that's right. Do you undertand?)

Yang lain juga ada kok yang salah, cuma mereka malu mau nanya. Iya gitu gak?

(There was also wrong in answering, they're just too shy to ask. Isn't that so?)

D7/C055/Revi : Awas ketauan pandenya ecek-ecek

(Be careful... somebody will know that they're not really smart)

In the other realization, the student frightened to the other students by saying "awas ketauan" and then there will be something happen to the hearer. His voice sounded like threat 
to his friends.

\title{
Seek disagreement
}

Seek disagreement means people did not always have the same feelings each other. There were 3 clauses realize with seek disagreement found by the researcher. It can be seen from the data below.

\author{
Data 4 \\ $\mathrm{T}$ \\ : Berdasarkan tugas yang kamu kerjakan, untuk Azzikra, Dinda, Dini, \\ Rani, Nurhalizah dan Sella dapat 100 \\ (Based on your task, for Azzikra, Dinda, Dini, Rani, Nurhalizah and \\ Sella, you get a hundred points) \\ Rif : Contek-contekan nya itu \\ (They cheated each other) \\ D4/C031/Sel : Mana ada contek-contekan bele \\ (We are not, foolish)
}

From the finding above, a student stated that "contek-contekan nya itu" because most of female students who get a hundred point, there was no male student. Besides that, the second statement "mana ada contek-contekan bele" is considered as disagreement because it was done as an attempt to refute the wrong statement from his male friend. Then, a female student gave her opinion because she believe that her other female friends do their own task.

\section{Use inappropriate identity marker}

There were 3 clauses realize with use inappropriate identity marker. It uses title, surname, or nick name when a close or distant relationship pertains. It can be seen from the representative data below.

\section{Data 9}

$\mathrm{T}$

: Setelah diabsen, ada tiga orang yang tak hadir atas nama Afina, Fajar dan Dika

(After being absent, there were three students who did not attend, they are Afina, Fajar and Dika)

D9/C062/Adl : Si BB bauk badan rumahnya jauh kali ya

(BB is odor, her house is far away from school)

The student uttered "Si BB bauk badan" which is used inappropriate identity marker because it used surname to call his friend, Afina with surname BatuBara. BB is not Bau Badan, but it stands for BatuBara, one of surname from Mandailing. In addition, there is also a representative data from use inappropriate identity marker. 


\section{Invade the other's space}

After analyzing the data, there was found 1 clause realizes with invade the other's space. Literally, invade the other's space is position yourself closer to the other than the relationship permits or metaphorically is ask for or speak about information which is too intimate given the relationship. It can be seen from the data display below.

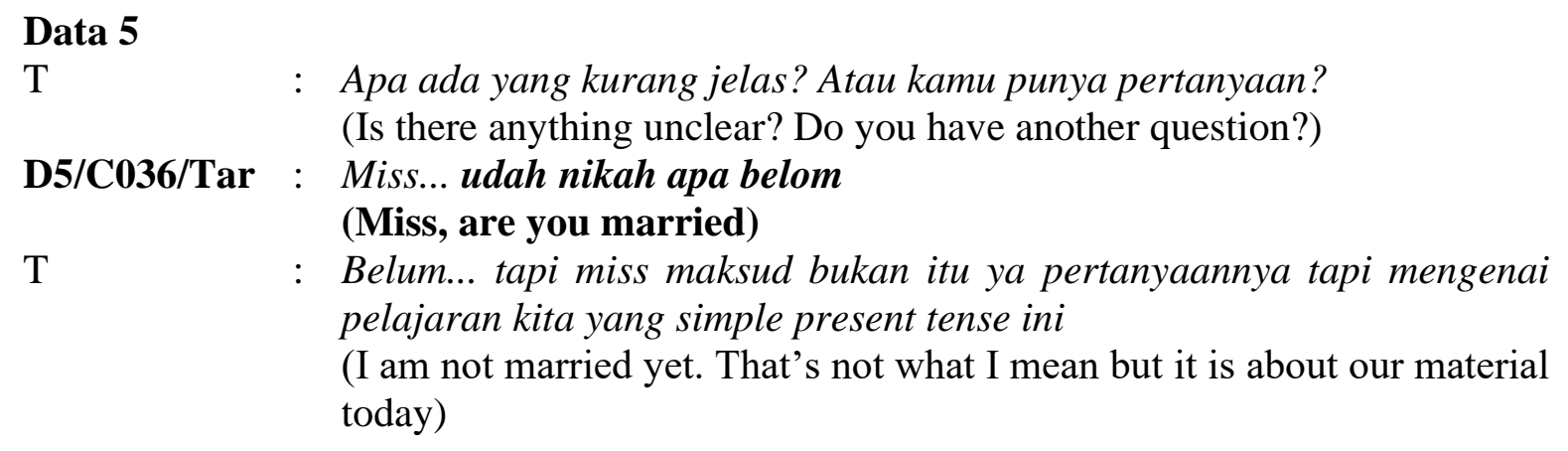

From the student's utterance above, it can be categorized as negative impoliteness part of invade the other's space because "miss... udah nikah apa belom" is a personal question. So, the student is not allowed to ask that question because the relationship between student and teacher are not closer than the relationship permits.

\section{Use obscure or secretive language}

The purposes of obscure or secretive language are to mystify the other with jargon and use a code known to others in the group, but not the target. After analyzing the data, it was found 1 clause realizes with use obscure or secretive language. It can be seen from the representative data below.

\section{Data 2}

$\mathrm{T}$

: Sudah masuk semua belum ini ya yang di rumah, kok lama kali masuknya.

(Has everyone at home joined Zoom? What took you so long)

Bentar ya miss tengok dulu

(Wait for a minute, I will go to check it)

D2/C011/Akb : Ngendog mungkin wong iku, miss

(Maybe, they are spawning)

Din : Ngendog apa?

(What is spawning?)

Akb : Nelor lho, Din...

(Spawning, Din...)

The student used obscure or secretive language by saying "ngendog mungkin wong iku, miss" used as a code known to others in the group, but not for the others which comes from 
Javanese language so that only certain people know the language. In Indonesian means "mungkin mereka lagi bertelur miss".

In accordance with data analysis and finding, dealing with the theory that proposed by Culpeper (1996), there are eight realizations found in this study. In addition, there were found other realizations from the clauses that have been analyzed, they are employing insincere; direct speech, clear, unambiguous; and invade the other's space. It different with the study comes from Anggraini (2016) who analyzed the impoliteness used by haters in celebrities' Instagram. She found 9 realizations of impoliteness strategies. In addition, she found two new realizations, namely insult and similes. This current research also contradictory with the research finding from Matondang (2018), she found realizations of impoliteness strategies in 2016 USA Presidential Election Debate were snub, disassociate with others, use dissected, seek disagreement, use taboo words, frighten, condescend, and explicitly associate other with negative aspects. In this case, she did not find additional realization from her study.

\section{CONCLUSION}

This study focused on the impoliteness clauses used by students in English online learning through Zoom during pandemic covid-19. It was aimed to elaborate the realization of impoliteness why the impoliteness used by students in English online learning through Zoom. The conclusion can be drawn as there were eleven realizations that realized by students in English online learning through Zoom during pandemic Covid-19, they are employing insincere; condescend, scorn or ridicule; direct speech, clear and unambiguous; use taboo words; call the other name; be disinterested, unconcerned, unsympathetic; frighten; seek disagreement; use inappropriate identity marker; invade the other's space; and use obscure or secretive language.

\section{REFERENCES}

Ally, M. (2006). Foundations of Educational Theory for Online Learning. Numero 1-2/2006 Anggriani, D. (2016). Impoliteness Used by Haters in Celebrities' Instagram. Master Thesis, Universitas Negeri Medan.

Bogdan, R C and S K, Biklen. (2007). Qualitative Research for Education: An Introduction to Theory and Methods 5th Edition. Boston: Allyn and Bacon.

Culpeper, J. (1996). Towards an Anatomy of Impoliteness. Journal of Pragmatics, 25 (3), 349-367.

Dagarin, M. (2004). Classroom Interaction and Comunication Strategies in Learning English 
as a Foreign. Elope: English Language Overseas Perspectives and Enquiries Volume 11 2: University of Ljubljana

Kementerian Riset, Teknologi dan Pendidikan Tinggi. (2016). Kebijakan Pendidikan Jarak Jauh dan E-Learning di Indonesia. Retrieved from http://kopertis3.or.id/v2/wpcontent/uploads/Paulina-Pannen-Kebijakan-PJJ-dan-E-Learning.pdf

Matondang, I I. (2018). Impoliteness Strategies in 2016 USA Presidential Election Debate. Master Thesis, Universitas Negeri Medan

Mishra, L., T, Gupta., and A, Shree. (2020). Online teaching-learning in higher education during lockdown period of COVID-19 pandemic. International Journal of Educational Research Open in press. 